\title{
The feeding behaviour of some demersal fish species in response to artificial discarding*
}

\author{
IGNACIO OLASO, FRANCISCO SÁNCHEZ, CRISTINA RODRÍGUEZ-CABELLO \\ and FRANCISCO VELASCO
}

Instituto Español de Oceanografía, P.O. Box 240, 39080, Santander, Spain. E-mail: iolaso@st.ieo.es

\begin{abstract}
SUMMARY: In an attempt to detect changes in the diet and the feeding intensity of demersal fish caused by fishery discarding, two hauls were carried out $22 \mathrm{~h}$ apart at a depth of $90 \mathrm{~m}$ in an area of the Cantabrian Sea closed to trawling. Before the second haul, dead fauna that were not common in the sampling area under natural conditions, such as Micromesistius poutassou and squat lobster (Munida spp.), which are both usually discarded by the fleet and mainly found in deeper water, were thrown overboard. A total of 319 stomach contents from 12 demersal fish species caught in both hauls were analysed. The percentage emptiness decreased in the second haul $(32 \%)$ with respect to the first $(43 \%)$, and at the same time the feeding intensity of scavenger species such as Trachinus draco, Pagellus acarne, Scyliorhinus canicula, Raja montagui and Leucoraja naevus increased. Discards of $M$. poutassou was actually found in the stomach of a typically planktophagous species, Pagellus bogaraveo. Observed changes in trophic structure of the species analysed as a response to discards are discussed.
\end{abstract}

Key words: Cantabrian Sea, diet, feeding behaviour, fisheries discards, scavengers.

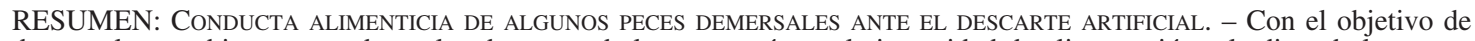
detectar los cambios que producen los descartes de las pesquerías en la intensidad de alimentación y la dieta de los peces demersales se realizaron, en un intervalo de tiempo de 22 horas, dos lances de arrastre de fondo semejantes a una profundidad de 90 metros y en un área cerrada a la pesca comercial de arrastre del Mar Cantábrico. Antes del segundo lance, se arrojó al mar fauna muerta que se encuentra en condiciones naturales en aguas más profundas, como Micromesistius poutassou y Munida spp, especies que suelen ser descartadas por la flota. Se analizaron 319 contenidos estomacales de 12 especies de peces demersales capturados en ambos lances. El porcentaje de estómagos vacíos decreció en el segundo lance (32\%) con respecto al primero (43\%), y al mismo tiempo aumentó la intensidad de alimentación de las especies carroñeras como Trachinus draco, Pagellus acarne, Scyliorhinus canicula, Raja montagui y Leucoraja naevus. La especie descartada M. poutassou se encontró en estómagos de la especie típicamente planctófaga Pagellus bogaraveo. Asimismo se discuten los cambios producidos en la estructura trófica de las especies analizadas como respuesta al alimento suplementario que constituye el descarte.

Palabras clave: Mar Cantábrico, dieta, conducta alimenticia, descartes pesqueros, carroñeros.

\section{INTRODUCTION}

In the course of fishing operations, species of no economic value are often discarded. Some discarded animals survive, but most die and provide scav-

*Received June 19, 2001. Accepted January 14, 2002. engers with additional food. When such discarded material is on or near the surface, it can be consumed by birds (Furness et al., 1988; Hudson and Furness, 1988; Camphuysen et al., 1995), but the balance sinks through the water column, where it may be consumed by pelagic scavengers such as fish, sharks and cetaceans. What is not consumed in 
the water column reaches the seabed and is eaten by benthic scavengers. Camphuysen et al. (1995) and Garthe et al. (1996) consider that $20 \%$ of discarded material (mainly gadoids and the contents of the body cavity) in the North Sea are consumed by birds, whereas the remaining $80 \%$ (e.g. echinoderms, molluscs) sink to the seabed. On the other hand, Oro and Ruiz (1997) noted that birds in the Mediterranean Sea can consume up to $>70 \%$ of fishery discards. According to Wassenberg and Hill (1987; 1990), 35\% of the discards in a Queensland shrimp fishery (mainly fish and cephalopods) is consumed on the surface and the other 65\% (crustaceans, echinoderms) reaches the seabed. Hill and Wassenberg (1990) set experimental discards for 10 minutes in the water column in a prawn fishery area, and found that at night $24 \%$ of it was consumed, probably by sharks. The quantum of discards can be considerable, as in the case of the North Sea (Garthe et al., 1996), but the proportion that reaches the seabed has not been estimated. Apart from the information listed above, it is well known that fishing activities damage or kill a proportion of non-captured fauna (Kaiser and Spencer, 1994; 1995); this damaged fauna constitutes an additional food source for fish and invertebrates living on the seabed. As a result, predators and scavengers congregate in such areas disturbed by bottom trawl fishing gear, occasionally changing their dietary preference accordingly (Kaiser and Spencer, 1994, 1996; Ramsay et al., 1996, 1998; Kaiser and Ramsay, 1997; Kaiser et al., 1998).

The response of scavengers to discards generated by a trawl fleet has been the subject of research mainly in northern European waters (Van Beek, 1990; Kaiser and Spencer, 1995, 1996; Kaiser and Ramsay, 1997). However, work has been carried out recently in other areas, for example the studies of Collins et al. (1999) on the Patagonian slope and Demestre et al. (2000) in the Mediterranean Sea. Few studies have been conducted in the Cantabrian Sea, where trawl discards constitute as much as $35 \%$ of the landed catch (i.e. 13,971 tons in 1994), some $24 \%$ of which is blue whiting Micromesistius poutassou, according to Pérez et al. (1996) one of the main species discarded by trawlers in the Cantabrian Sea. In the same area, Olaso et al. (1998) investigated the importance of discarded M. poutassou in the diet of lesser-spotted dogfish, Scyliorhinus canicula; it represented a high percentage of the diet. As discards constitute an important food source for some demersal species, the current experiment was carried out to determine which species of fish benefit from discards as a food source and what is the effect of the discards on their feeding intensity and dietary composition.

\section{MATERIAL AND METHODS}

In the Cantabrian Sea (ICES Division VIIIc), the bottom trawl fleet is not permitted to operate inshore of the $100 \mathrm{~m}$ isobath, although there is illegal trawling in some areas. To prevent this practice, antitrawling concrete blocks, forming artificial reefs, were installed from 1992 in some sectors of the study area, at depths of 30-100 m. The introduction of artificial reefs is designed to form a dense barrier, making the area impracticable for trawling. Nevertheless, by carrying out scientific monitoring studies in such an area closed to trawling, a research vessel can provide valuable information from a single halfhour trawl between the blocks. Since the installation of the artificial reefs, commercial fishing in the area has been mainly by gillnet and longline.

In order to analyse changes in the fauna of the area attributable to the installation of trawl deterrents, abundance indices were obtained from bottom trawl surveys conducted every autumn between 1988 and 1999 according to a standard methodology (Sánchez, 1993; Anon., 1997; Sánchez et al., 1998). For the purposes of this investigation, two hauls (H1 and H2) were carried out at a depth of $90 \mathrm{~m}$ during the 1999 bottom-trawl survey, in the area where trawl deterrents had been installed (in the central Cantabrian Sea). The first haul (H1) was carried out at 17:00. Then, before nightfall (19:00), $50 \mathrm{~kg}$ batches of Micromesistius poutassou were thrown overboard at regular intervals (to a total of $1,500 \mathrm{~kg}$ ) following the same course of haul $\mathrm{H} 1$, using a navigation plotter and DGPS (Global Positioning System with Differential correction) system (precision $\pm 5 \mathrm{~m}$ ). In addition, at about the middle of the trawl track, $150 \mathrm{~kg}$ of squat lobster, Munida sarsi and $M$. intermedia, were thrown overboard in $50 \mathrm{~kg}$ batches. These species (Micromesistius poutassou and Munida spp.) are not found within the area where the experiment was carried out, because they live in deeper water (Olaso, 1990; Sánchez, 1993). As a result, they are not the usual prey of predators in the area. To guarantee that the material reached the bottom and was not consumed by seabirds or other animals in the water column, each $50 \mathrm{~kg}$ batch was thrown into the sea as a partially frozen compact 
block. Some $20 \mathrm{~h}$ after the material had been discarded and $22 \mathrm{~h}$ after trawl $\mathrm{H} 1$, a parallel trawl (H2) was carried out along a track $30 \mathrm{~m}$ from $\mathrm{H} 1$. In both hauls, the trawling time (30 min), vessel speed (3 knots) and gear were identical, and the area calculated to have been covered by the gear was 51,586 $\mathrm{m}^{2}$. The swept area was obtained from the start and end locations of the trawl track, and the gear horizontal opening (wing spread $=19.8 \pm 1.9 \mathrm{~m}$ ) was provided by SCANMAR equipment. In order to obtain evidence to test the hypothesis that predators and scavengers move towards areas disturbed by bottom-trawl gear, any changes in the abundance of fish and mobile epibenthos between the two hauls were noted specifically.

After sorting and weighing the catch, the stomach contents of 12 demersal fish species, abundant in both hauls, were analysed aboard ship. Where possible, the minimum sample size per length range was 10 animals. For each predator, the data collected were length to the $\mathrm{cm}$ below, sex and maturity stage. In addition, the state of the gall bladder (Robb, 1992) was examined in all fish except sharks and skates, to separate the stomachs that were really empty from those of specimens that had regurgitated food shortly before being caught. Stomachs containing food that had been ingested during the haul itself (i.e. the gall bladder had not been used) were considered empty. The total stomach content of fish with food was measured by volume $(\mathrm{ml})$ using a trophometer (Olaso et al., 1998). The stomach content weight was derived from a regression equation using the estimated volume and actual weight of the contents, as described by Olaso $\left(1990 ; \mathrm{a}=0.932735, \mathrm{~b}=0.99324, r^{2}=0.99\right.$; $p<0.01)$. Prey was identified to the lowest possible taxon in the case of decapod crustaceans and fish; other invertebrates were classified to a higher taxonomic level. For each prey type, the data collected were percentage contribution to the total stomach content volume, number of items per stomach and the state of digestion ( $1=$ intact prey; 2 = partiallydigested prey; 3 = well-digested prey). To examine the relationship between prey and predator size, measurements of prey weight $(\mathrm{g})$ and size were taken. For size, the total length $(\mathrm{mm})$ of fish and the total length from the tip of the head to the end of the telson $(\mathrm{mm})$ of crustaceans were recorded. For prey where the determination of these measurements was impossible (i.e. incomplete prey or prey in an advanced state of digestion), the length of the hard structures was measured. In the case of fish, the otolith size was measured to the nearest $\mathrm{mm}$, and the length was estimated from regressions of fish length against otolith length (Pereda and Villamor, 1991). In the case of crustaceans, the carapace, chelae or propodus length in decapod crustaceans was measured to the nearest $\mathrm{mm}$, and the length was also estimated from regressions of crustacean length against hard structure length (RodríguezMarín, 1993; Olaso and Rodríguez-Marín, 1995b). Micromesistius poutassou found in the stomachs of predators (Munida sarsi and M. intermedia were not found at all) were considered to be discards that had been consumed.

To analyse diet, the percentage indices used were expressed by number $(\% N)$ and volume $(\% V)$, as described by Hyslop (1980). Additionally, in order to compare the feeding intensity between species and hauls, a partial (PFI) and total fullness index (TFI) were used together with a fullness index $(\% B W)$. PFI and TFI were proposed for use in such research by Bowering and Lilly (1992) and, in the present study, were calculated as a mean per haul from the formulae

$$
\begin{gathered}
P F I_{i}=\frac{\sum_{h=1}^{H}\left[\frac{F+R}{F \times(F+R+E)} \times \sum_{j=1}^{k} \frac{V_{i j}}{L_{j}^{3}}\right]}{H} \\
\text { and } \\
T F I=\sum_{i=1}^{x} P F I_{i}
\end{gathered}
$$

where $F, R$ and $E$ are respectively the number of full, regurgitated and empty stomachs of the studied predator species in haul $h, V_{i j}$ is the volume of prey $i$ in stomach $j, k$ the number of stomachs in the haul $h, L_{i}$ the length of predator $j, H$ the total number of hauls in which stomachs of the predator species were analysed, and $X$ is the total number of different prey categories consumed by the predator throughout the study. The $\% B W$ is the wet weight of stomach contents expressed as a percentage of the fish body weight; it was also calculated as a mean for each species by haul using the regurgitated correction factor. PFI and TFI normalize the stomach content data in relation to size of predator and $\% B W$ normalizes them by weight. Both indices allow comparison of predator samples with different size distributions. In addition, the percentage of empty stomachs was recorded. The significance of the dif- 
ferences in mean stomach fullness per predator species between the first and second hauls was determined with the Mann-Whitney $U$-test, when the sample size was larger than 25 fish for both hauls together. Differences in emptiness percentage by predator species were tested by means of a Chisquared test and, because of the small sample size, the Yates correction was also calculated for all the species. The diversity of the sample obtained in each haul was estimated with the Shannon-Wiener diversity index, $H^{\prime}$ (Shannon and Weaver, 1949):

$$
H^{\prime}=-\sum_{i=1}^{S} p_{i} \times \log _{2}\left(p_{i}\right)
$$

where $p_{i}$ is the proportion of the total sample belonging to the $i$ th species and $S$ is the total number of species caught in the corresponding haul.

\section{RESULTS}

\section{Changes in demersal fish biomass between 1988 and 1999}

The biomass indices (expressed in $\mathrm{kg}$ per $30 \mathrm{~min}$ haul) from bottom trawl surveys carried out before and after the creation of the closed trawl area were used to determine the impact of this management measure. The period 1988-1991 was before and the period 1996-1999 was after the installation of trawl deterrents. The indices show that the biomass of some of the species analysed in the study increased when the area was closed (Fig. 1). The most notable increases were in skates and Scyliorhinus canicula, and in Trachinus draco, Mullus surmuletus, Pagellus acarne and gurnards (Triglidae). In contrast, there was no increase in biomass of Lepidorhombus whiffiagonis and Merluccius merluccius, both of which actually decreased slightly. One possible explanation is that the closed area is not an appropriate habitat for the latter two species because they prefer deeper water (Sánchez, 1993). Apart from these two, there was a general increase in both biomass and number of species once the trawl fleet stopped operating in the area.

\section{Catches during the experiment}

The total catch was larger and the diversity index higher in the second experimental haul than in the first; this statement reflects both fish and invertebrates (Table 1). The few fish species whose catch increased notably belonged to the family Sparidae (Pagellus acarne, P. bogaraveo, P. erithrynus, Boops boops), and the invertebrates displaying a greatly increased catch in haul $\mathrm{H} 2$ included the portunid Polybius henslowii and the squid Loligo forbesi (Fig. 1). The most abundant species in the first haul were Trachurus trachurus and Sepia officinalis. However, most species either showed no difference in the catch rate between the two hauls or the catch was smaller in the second haul.

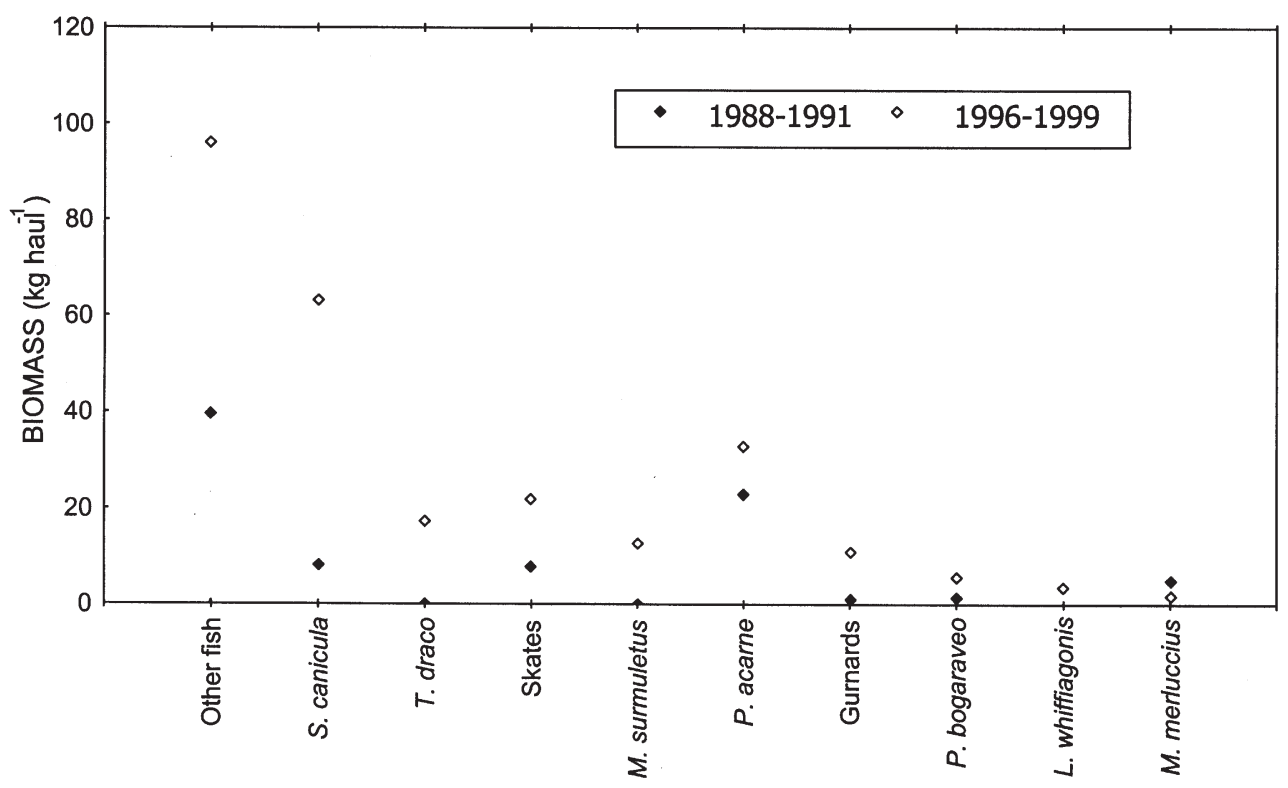

FIG. 1. - Changes in historical biomass indices of species determined from bottom trawl surveys carried out in the study area. The period 1988-1991 was before and the period 1996-1999 after the installation of trawl deterrents. 
TABLE 1. - Catch weight and number of species found in hauls H1 and H2.

\begin{tabular}{|c|c|c|c|c|}
\hline \multirow[b]{2}{*}{ Fish species studied } & \multicolumn{2}{|c|}{ Catch in haul 1 (H1) } & \multicolumn{2}{|c|}{ Catch in haul $2(\mathrm{H} 2)$} \\
\hline & Weight $(\mathrm{g})$ & Number & Weight $(\mathrm{g})$ & Number \\
\hline Chelidonichthys cuculus & 3555 & 43 & 6295 & 41 \\
\hline Callionymus lyra & 2680 & 27 & 2230 & 29 \\
\hline Lepidorhombus wiffiagonis & 5500 & 27 & 2610 & 12 \\
\hline Merluccius merluccius & 3540 & 5 & 1535 & 6 \\
\hline Mullus surmuletus & 28600 & 110 & 19920 & 86 \\
\hline Pagellus acarne & 31900 & 150 & 222800 & 2017 \\
\hline Pagellus bogaraveo & 22550 & 131 & 116050 & 891 \\
\hline Raja montagui & 10350 & 8 & 2175 & 3 \\
\hline Leucoraja naevus & 14450 & 7 & 6295 & 5 \\
\hline Scyliorhinus canicula & 65350 & 100 & 21465 & 47 \\
\hline Trachinus draco & 23200 & 210 & 18800 & 240 \\
\hline Chelidonichthys lucerna & 5020 & 7 & 6550 & 4 \\
\hline \multicolumn{5}{|l|}{ Other fish species } \\
\hline Trachurus trachurus & 121100 & 3583 & 83050 & 1444 \\
\hline Boops boops & 3845 & 32 & 20750 & 216 \\
\hline Pagellus erythrinus & 3090 & 5 & 10200 & 17 \\
\hline Raja clavata & 18300 & 6 & 4665 & 2 \\
\hline Psetta maxima & & & 2540 & 1 \\
\hline Conger conger & & & 1485 & 1 \\
\hline Zeus faber & 15150 & 5 & 1440 & 1 \\
\hline Argentina sphyraena & 1930 & 69 & 1100 & 36 \\
\hline Solea vulgaris & 1625 & 4 & 385 & 1 \\
\hline Aspitrigla obscura & 1735 & 10 & 175 & 1 \\
\hline Arnoglossus imperialis & 505 & 26 & 75 & 3 \\
\hline Dicentrarchus labrax & 2905 & 1 & & \\
\hline Raja undulata & 1365 & 1 & & \\
\hline Microchirus variegatus & 365 & 7 & & \\
\hline Serranus cabrilla & 85 & 1 & & \\
\hline \multicolumn{5}{|l|}{ Invertebrates } \\
\hline Polibius henslowi & & & 5210 & 396 \\
\hline Loligo forbesi & 45 & 1 & 3200 & 24 \\
\hline Loligo vulgaris & 3800 & 7 & 2420 & 5 \\
\hline Octopus vulgaris & 90 & 1 & 2280 & 3 \\
\hline Sepia officinalis & 2145 & 3 & 645 & 1 \\
\hline Charonia lampax & 395 & 1 & 345 & 1 \\
\hline Pagurus prideauxi & S95 & & 15 & 2 \\
\hline Illex coindetti & 395 & 4 & & \\
\hline Sepia orbignyana & 45 & 1 & & \\
\hline Pagurus excavatus & 30 & 3 & & \\
\hline All species & 395640 & 4596 & 566705 & 5536 \\
\hline
\end{tabular}

\section{Change in diet}

Of the material discarded into the sea, Munida spp. was not found in the stomach contents analysed in $\mathrm{H} 2$, but M. poutassou was recovered. Of the 12 species with stomach contents in both hauls, Lepidorhombus whiffiagonis, Mullus surmuletus, Callionymus lyra, Merluccius merluccius and Chelidonichthys lucerna apparently did not take advantage of the discards. Of these five species, dietary differences between hauls were only observed for Lepidorhombus whiffiagonis, which in $\mathrm{H} 2$ preyed more on crustaceans and less on fish (Fig. 2) than in H1. Of the other seven species, all of which had eaten the discarded Micromesistius poutassou to a greater or lesser extent, those that seemingly took greatest advantage were Pagellus bogaraveo and Scyliorhinus canicula. However, notable differences between hauls were also observed in the diets of Leucoraja naevus and Pagellus acarne. Chelidonichthys cuculus only consumed a small amount of Micromesistius poutassou. In haul H1, the stomachs of Scyliorhinus canicula contained discarded Sardina pilchardus, probably originating from longliners working in the same area.

In the stomachs of those fish species from $\mathrm{H} 2$ that had not consumed Micromesistius poutassou, there was a slight increase in the average weight of prey with respect to $\mathrm{H} 1$, although this was almost imperceptible in Chelidonichthys lucerna (Table 2). Nevertheless, fish that had eaten discarded Micromesistius poutassou, such as Scyliorhinus canicula and Raja montagui, had an average weight of that prey species that exceeded 3-4 times the average weight of their other prey. In the case of Pagellus acarne and $P$. bogaraveo, this relationship was 


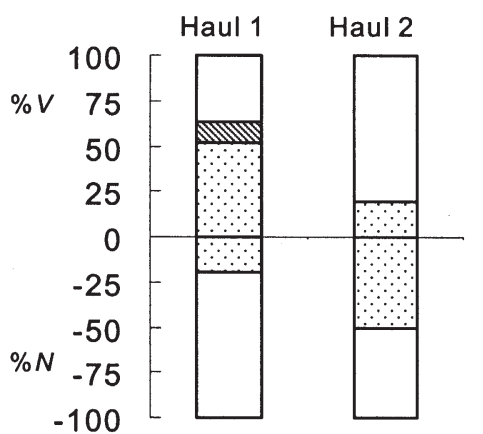

L. whiffiagonis

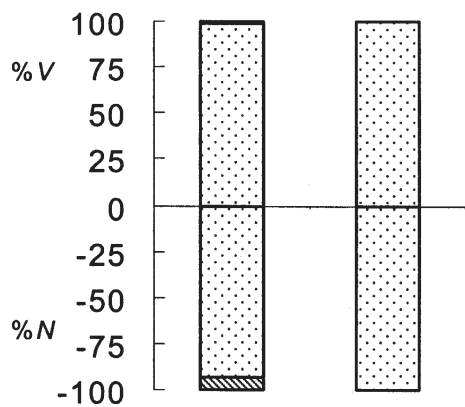

C. lucerna
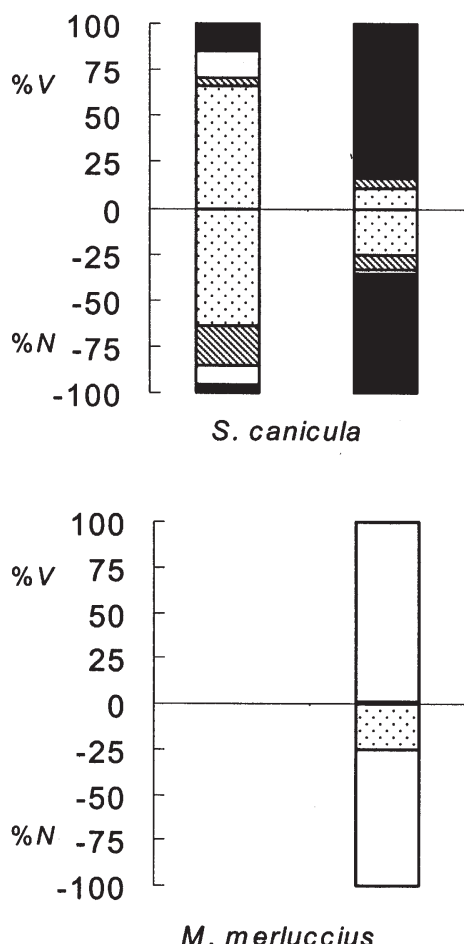

M. merluccius

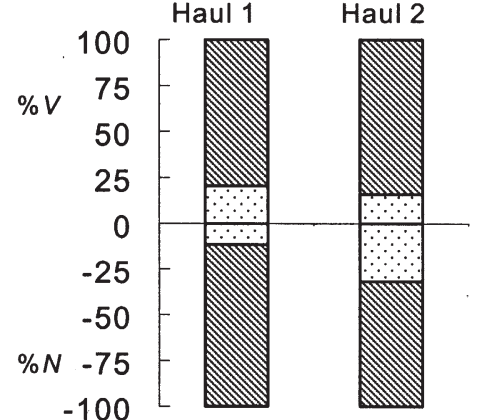

M. surmuletus

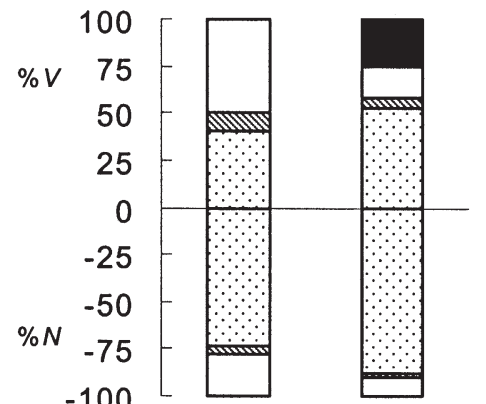

C. cuculus

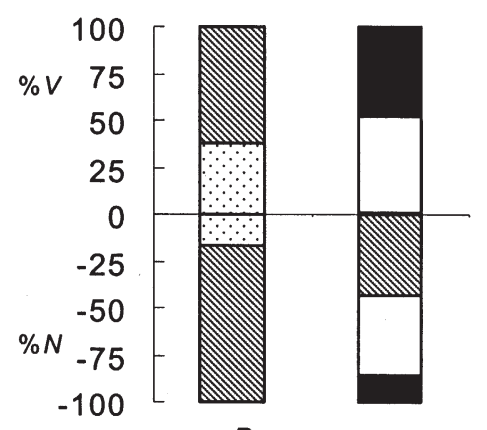

P. acarne

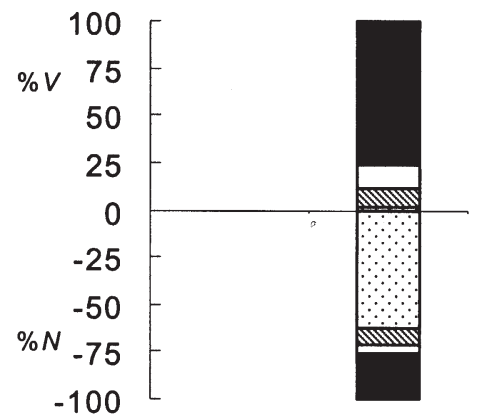

T. draco

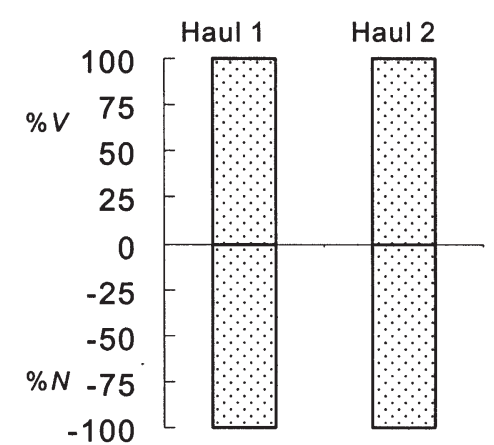

C. Iyra

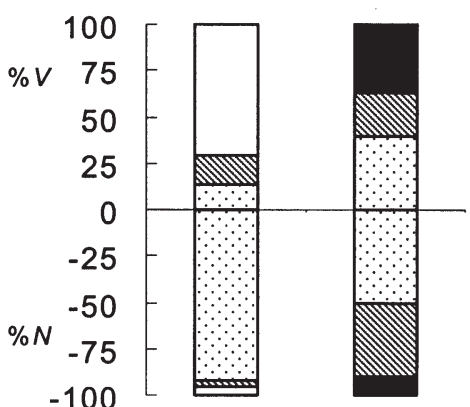

R. montagui

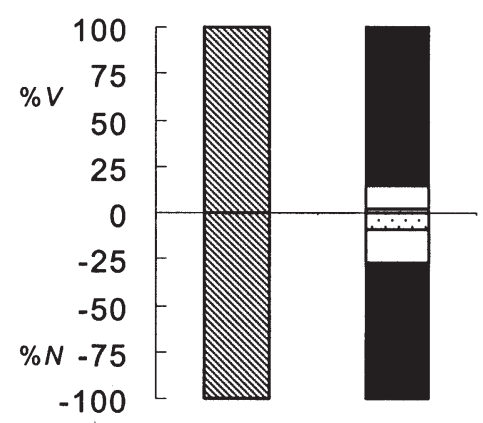

P. bogaraveo

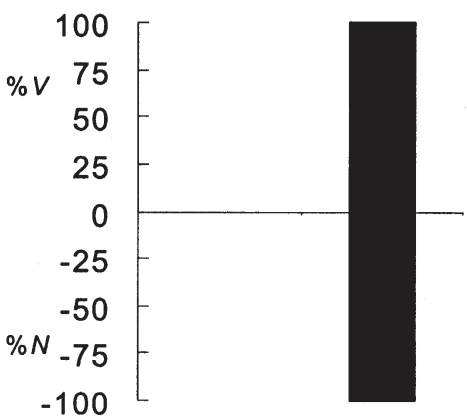

L. naevus
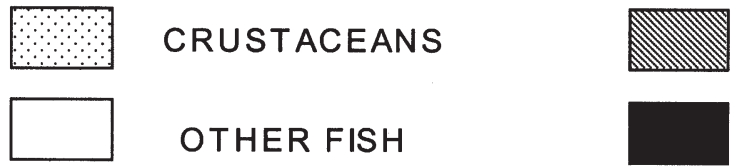

OTHER INVERTEBRATES

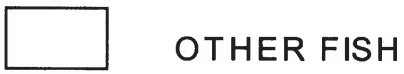

DISCARDS

FIG. 2. - Composition of prey groups in predator stomachs for two hauls carried out in the same place in an area where there is no commercial trawling, before (Haul 1) and after (Haul 2) artificial discarding. Data are expressed as percentages by volume $(\% V)$ and number $(\% N)$. 
TABLE 2. - Average prey weight and total number of prey per predator species in hauls $\mathrm{H} 1$ and $\mathrm{H} 2$, and the average weight and total number of blue whiting prey per predator species in haul $\mathrm{H} 2$.

\begin{tabular}{|c|c|c|c|c|c|c|}
\hline \multirow[b]{2}{*}{ Predator } & \multicolumn{2}{|c|}{ Prey in haul 1 (H1) } & \multicolumn{4}{|c|}{ Prey in haul 2 (H2) } \\
\hline & $\begin{array}{l}\text { Average weight of } \\
\text { natural prey }(\mathrm{g})\end{array}$ & $\begin{array}{l}\text { Number } \\
\text { of prey }\end{array}$ & $\begin{array}{l}\text { Average weight } \\
\text { of natural prey }(\mathrm{g})\end{array}$ & $\begin{array}{l}\text { Number } \\
\text { of prey }\end{array}$ & $\begin{array}{l}\text { Average weight } \\
\text { of blue whiting prey }(\mathrm{g})\end{array}$ & $\begin{array}{l}\text { Number of } \\
\text { blue whiting }\end{array}$ \\
\hline Raja naevus & & & 0.00 & 0 & 35.57 & 8 \\
\hline Scyliorhinus canícula & 4.99 & 61 & 3.93 & 32 & 11.55 & 58 \\
\hline Pagellus acarne & 0.10 & 66 & 2.12 & 12 & 11.46 & 2 \\
\hline Pagellus bogaraveo & & & 2.45 & 3 & 8.27 & 8 \\
\hline Raja montagui & 0.65 & 24 & 3.26 & 9 & 11.01 & 1 \\
\hline Chelidonichthys cuculus & 0.11 & 80 & 0.07 & 213 & 5.53 & 1 \\
\hline Trachinus draco & & & 0.26 & 16 & 2.54 & 5 \\
\hline Chelidonichthys lucerna & 8.94 & 14 & 10.31 & 6 & & \\
\hline Lepidorhombus wiffiagonis & 0.37 & 10 & 0.47 & 4 & & \\
\hline Mullus surmuletus & 0.22 & 285 & 0.78 & 91 & & \\
\hline Callionymus lyra & 0.09 & 14 & 0.28 & 2 & & \\
\hline Merluccius merluccius & & & 9.49 & 4 & & \\
\hline
\end{tabular}

TABLE 3. - Percentage stomach emptiness by haul and predator, together with the significance shown by the $\chi^{2}$ test and the Yates correction.

\begin{tabular}{|c|c|c|c|c|c|c|}
\hline \multirow[b]{2}{*}{ Predator } & \multicolumn{2}{|c|}{ Haul 1} & \multicolumn{3}{|c|}{ Haul 2} & \multirow[b]{2}{*}{ Yates } \\
\hline & Number sampled & $\%$ empty & Number sampled & $\%$ empty & $\mathrm{p}\left(\operatorname{distr} \chi^{2}\right)$ & \\
\hline Chelidonichthys cuculus & 19 & 31.58 & 28 & 7.14 & 0.029 & 0.073 \\
\hline Callionymus lyra & 5 & 20.00 & 9 & 77.78 & 0.036 & 0.126 \\
\hline Lepidorhombus wiffiagonis & 22 & 72.73 & 12 & 75.00 & 0.886 & 1.000 \\
\hline Merluccius merluccius & 5 & 100.00 & 6 & 100.00 & & \\
\hline Mullus surmuletus & 10 & 0.00 & 15 & 0.00 & & \\
\hline Pagellus acarne & 10 & 20.00 & 10 & 0.00 & 0.136 & 0.456 \\
\hline Pagellus bogaraveo & 9 & 55.56 & 10 & 0.00 & 0.006 & 0.026 \\
\hline Raja montagui & 7 & 28.57 & 3 & 0.00 & 0.301 & 0.863 \\
\hline Leucoraja naevus & 6 & 83.33 & 5 & 40.00 & 0.137 & 0.391 \\
\hline Scyliorhinus canicula & 29 & 6.90 & 43 & 11.63 & 0.506 & 0.796 \\
\hline Trachinus draco & 9 & 100.00 & 21 & 57.14 & 0.019 & 0.056 \\
\hline Chelidonichthys lucerna & 7 & 0.00 & 4 & 25.00 & 0.165 & 0.766 \\
\hline
\end{tabular}

almost 10 times greater. However, in species such as Trachinus draco and Leucoraja naevus, the stomachs were all empty in the first haul and full in the second.

\section{Feeding intensity}

The combined emptiness percentage for all fish species studied was greater in $\mathrm{H} 1(43 \%)$ than in $\mathrm{H} 2$ $(32 \%)$. The percentage decreased in the species eating Micromesistius poutassou and increased in those that had not taken advantage of the discarded material. Differences in the percentage of empty stomachs between $\mathrm{H} 1$ and $\mathrm{H} 2$ were only significant for four predator species (Table 3). However, when the Yates correction was applied as a result of a small sample size, the differences were only significant for Pagellus bogaraveo, whereas for Trachinus draco the probability of the $\chi^{2}$ value was 0.06 . For the mean stomach fullness per predator species in volume terms, the differences between both hauls were only significant in the case of Scyliorhinus canicula (Mann-Whitney $U$-test $=294.5 ; p=$ 0.006).

The changes in feeding intensity measured in terms of TFI for both hauls were important in some species. Some, such as Chelidonichthys lucerna and Callionymus lyra, did not consume additional discarded food and their feeding intensity dropped in H2. Also, although the feeding intensity of Merluccius merluccius increased, there were practically no significant differences in the feeding intensity of other predators, which seemingly took no advantage of the discards (Fig. 3).

Feeding intensity between hauls increased in all fish species that had consumed Micromesistius poutassou (Fig. 3), but the increase differed according to species. The increase was notable in Pagellus acarne, Leucoraja naevus, and even larger in Pagellus bogaraveo. Conger conger preyed on Micromesistius poutassou in $\mathrm{H} 2$, but it did not appear in $\mathrm{H} 1$, so it is not shown in Figure 3. 


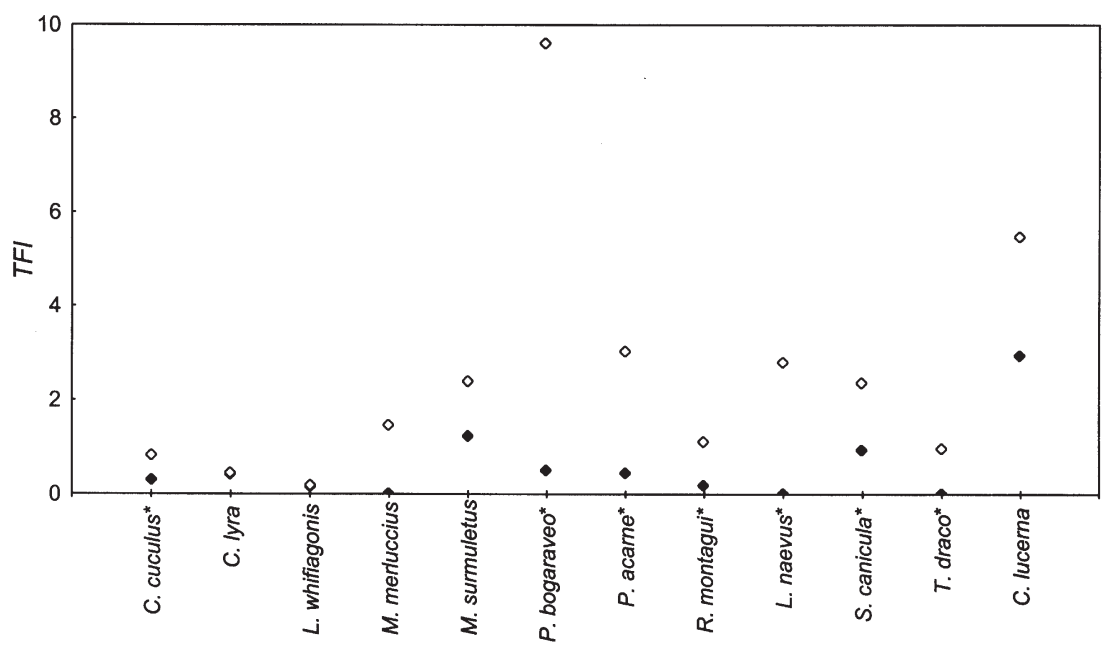

FIG. 3. - Comparison of the feeding intensity of demersal species in the two hauls. Species shown with an asterisk consumed M. poutassou. Data are expressed as total fullness index (TFI).
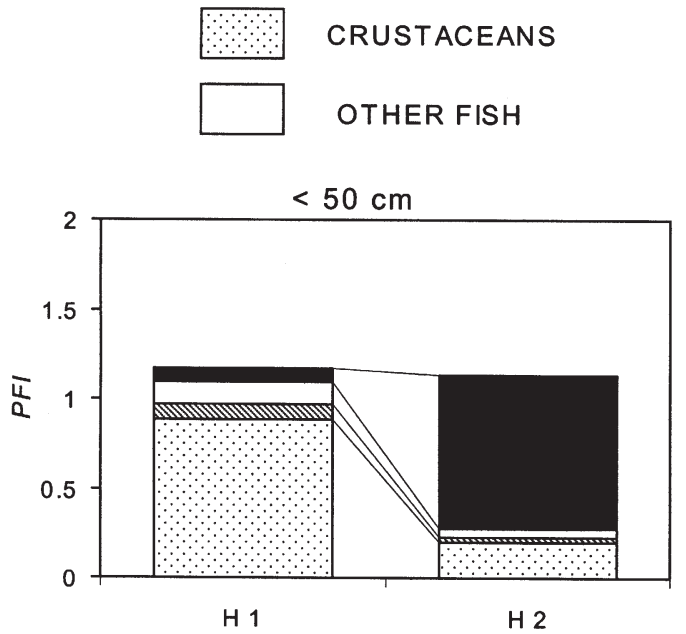

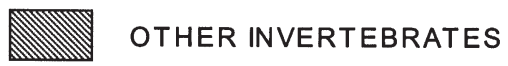

DISCARDS

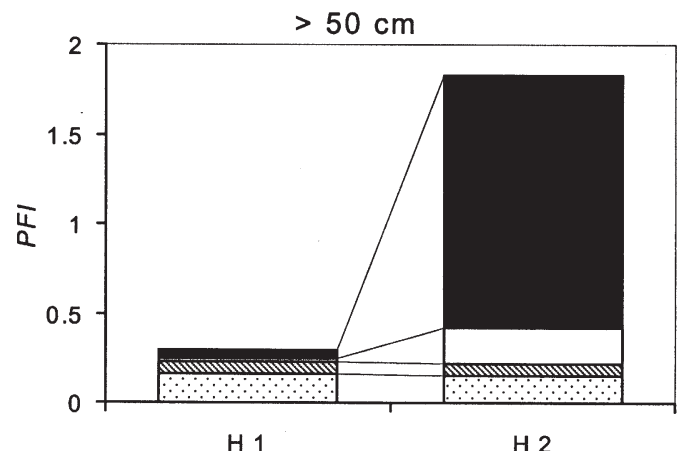

FIG. 4. - The relative importance of discards ingested by mature $(>50 \mathrm{~cm})$ and immature $(<50 \mathrm{~cm})$ lesser-spotted dogfish during hauls $\mathrm{H} 1$ and H2. Data are expressed as partial fullness index $(P F I)$.

Table 4. - Average prey weight per haul in the stomach contents of lesser-spotted dogfish.

\begin{tabular}{|c|c|c|c|c|}
\hline \multirow[b]{2}{*}{ Prey } & \multicolumn{2}{|c|}{ Prey weight (g) in haul 1 (H1) } & \multicolumn{2}{|c|}{ Prey weight (g) in haul 2 (H2) } \\
\hline & Dogfish $<50 \mathrm{~cm}$ & Dogfish $>50 \mathrm{~cm}$ & Dogfish $<50 \mathrm{~cm}$ & Dogfish $>50 \mathrm{~cm}$ \\
\hline Fish & $8.97 \pm 4.229$ & $4.48 \pm 6.416$ & & $12.33 \pm 1.724$ \\
\hline Crustaceans & $3.97 \pm 2.714$ & $3.75 \pm 1.836$ & $2.93 \pm 1.544$ & $4.64 \pm 2.643$ \\
\hline Other invertebrates & $3.32 \pm 3.073$ & $4.06 \pm 4.569$ & $2.86 \pm 5.160$ & $3.01 \pm 2.850$ \\
\hline Sardine discards from longline operations & $13.74 \pm 0.000$ & $11.01 \pm 4.570$ & & \\
\hline $\begin{array}{l}\text { Blue whiting discards } \\
\text { Blo }\end{array}$ & & & $8.56 \pm 2.100$ & $7.28 \pm 0.000$ \\
\hline Total prey & $3.88 \pm 1.974$ & $3.52 \pm 1.570$ & $6.05 \pm 1.592$ & $9.92 \pm 1.615$ \\
\hline
\end{tabular}

\section{Feeding of lesser-spotted dogfish}

The biomass of lesser-spotted dogfish has increased tremendously since the artificial reef blocks were installed and, because it is characteristically a scavenger (Olaso et al., 1998), its diet is worth analysing in detail here. The diet was com- pared using two size ranges, those $<50 \mathrm{~cm}$ being considered immature and those $>50 \mathrm{~cm}$ as mature (Rodríguez-Cabello et al., 1998). Immature Scyliorhinus canicula had a similar TFI in both hauls, but $80 \%$ of the food in $\mathrm{H} 2$ was Micromesistius poutassou; at the same time, decapod crustaceans were not important. In contrast, the TFI of mature 
lesser-spotted dogfish was much higher in $\mathrm{H} 2$ than in $\mathrm{H} 1$, the increase being attributable to the high PFI contributed by Micromesistius poutassou (Fig. 4). The average weight of lesser-spotted dogfish prey was greater in $\mathrm{H} 2$ than in $\mathrm{H} 1$, both for immature $(6.05$ v. $3.88 \mathrm{~g})$ and mature animals $(9.92$ v. $3.52 \mathrm{~g}$; Table 4). There were no inter-haul differences in crustacean or other invertebrate prey.

\section{DISCUSSION AND CONCLUSIONS}

Research on demersal scavenger species has shown that fish tend to move towards areas disturbed by trawling (Hall et al., 1993; Kaiser and Spencer, 1994; Collins et al., 1999; Demestre et al., 2000) and that fauna discarded or damaged by the gear is an important source of food for certain species (Evans et al., 1996; Kaiser and Spencer, 1994, 1995, 1996; Kaiser and Ramsay, 1997; Olaso et al., 1998; Ramsay and Kaiser, 1998; Ramsay et al., 1998). For instance, lesser weevers Echiichthys vipera are attracted by aggregations of scavenging shrimps and gobiids that constitute their natural prey (Lindeboom and De Groot, 1998), as well as pelagic portunid crabs that only appear after trawling (Wassenberg and Hill, 1987). In the current study, "baiting" the seabed with Micromesistius poutassou resulted in a considerable increase in the abundance of the sparids Pagellus bogaraveo and P. acarne and the portunid crab Polibius henslowii. The feeding intensity of sparids and typical generalist species such as Scyliorhinus canicula and skates, as well as that of more specialist species such as Trachinus draco, increased notably as a result of discarding Micromesistius poutassou. However, although the abundance of two other sparids, Boops boops and Pagellus erythrinus, increased, their diet was not analysed because of their preference for a pelagic habitat. All species mentioned, except Pagellus bogaraveo and $P$. erythrinus, are benthic in behaviour and feeding pattern, and their biomass has increased since trawling was halted in the study area (Fig. 1). Although none are target species of the commercial fishery, there is some commercial interest in them, but when they are discarded their survival is practically nil, except for Scyliorhinus canicula (Kaiser and Spencer, 1995; Olaso et al., 1998).

There is a time limit within which scavenging fish benefit from additional food available as a result of trawling. For instance, according to Kaiser and Spencer (1994), the stomach contents of gurnards, dogfish and whiting in recently trawled areas indicate that they consume benthos damaged by trawling up to two days after the initial disturbance, but thereafter consumption of such material drops off rapidly. The same authors also noted that the diet of gurnards and whiting in disturbed areas contained a high proportion of small amphipods, whose availability rises after bottom trawling. Therefore, even though there is evidence from the literature that small dragonets, gurnards, red mullet, small cod and other fish species consume discards (Lindeboom and De Groot, 1998), they seem to prefer small benthic fauna. The current work only provides information on opportunistic and scavenging species that prey on large discarded Micromesistius poutassou, material that is larger than the average prey size to which small predators are accustomed as food (Table 2).

Lesser-spotted dogfish and skates, as well as fish of the genus Pagellus, benefited most from the additional source of food provided by discards. However, the material was by far of greatest importance for mature lesser-spotted dogfish. Olaso et al. (1998) observed that the diet of lesser-spotted dogfish on trawling grounds contained up to $20 \%$ discarded Micromesistius poutassou. The present results therefore reinforce the belief that discarded Micromesistius poutassou is consumed by a considerable number of demersal fish species which, under natural conditions, would normally not have it available (Olaso and Velasco, in prep.). Nevertheless, large prey is generally scarcer than small prey. For a marine organism, as for any animal organism, the ingested food particles must be large enough to compensate for the energy spent searching for, chasing and eating them (Charnov, 1976). It is well known that the size of prey of the vast majority of marine fish increases in accord with predator size (Kislalioglu and Gibson, 1976; Kock, 1992; Scharf et al., 2000); the same has been observed specifically in the area of this study (Olaso and RodríguezMarín, 1995b; Velasco and Olaso, 1998). Therefore, the food selection by such fish is based upon evaluation of the relative size of the food particle in relation to their own size, preferred food generally being smaller than they are but as big as their mouths and digestive systems allow. However, suitably sized food is not always available; at such times prey size has to be substituted for by abundance. In this respect, Pagellus acarne and P. bogaraveo, specifically the former because it is usually a predator of small benthic or pelagic crustaceans (Olaso and 
Rodríguez-Marín, 1995a; Velasco et al., 1996), stand out as opportunistic fish capable of profiting from an occasional source of food that is different from their normal diet.

Pagellus acarne and P. bogaraveo clearly took advantage of the experimentally discarded Micromesistius poutassou, and although no stomach samples of Polibius henslowii were taken, it is assumed that that, species was also attracted by the abundance of carrion. As other surveys have shown that the numbers of Polibius henslowii increase when there is a carcass of a large animal in the net, it is fair to assume that this crab also obtains food in this way. During this experiment on 12 species of fish, $1,181.4 \mathrm{~g}$ of discarded Micromesistius poutassou were found in the stomachs of eight species. The total weight of the stomach contents for those eight species was $1,383.69 \mathrm{~g}$. In other words, $85 \%$ of the total stomach contents were discards, implying that, for those species at least, the additional food source provided by discarded material is important. However, it may well be that the supply of food in the form of discards during this experiment was somewhat unusual in that all the discarded material reached the bottom because it was frozen and discarded at night. Under natural conditions, the influence of the discarded material might not be so considerable. For example, Wassenberg and Hill (1987; 1990) stated that about $30 \%$ of the diet of some scavenger species could be provided by discards, but no data are available to test this hypothesis critically. Further, data from Laptikhovsky and Fetison (1999) indicated that squid discarded by fishing vessels contribute $20-40 \%$ by volume of the demersal diet of Merluccius hubbsi, Patagononotothen ramsayi and Macrourus holotrachys.

In summary, discards seem to be a relatively important food source for the bottom scavengers analysed in this study. However, the conclusions drawn would have been firmer if there had been an opportunity to undertake more hauls after the first two, as done in other studies (e.g. Ramsay et al., 1996, 1998). Unfortunately, that was impractical owing to other priority objectives of the survey. Nevertheless, certain conclusions are sound, namely that:

- predators and scavenger species such as Pagellus acarne and $P$. bogaraveo may move to areas disturbed by bottom trawling in order to prey on discarded or damaged material;

- planktophagous species such as Pagellus bogaraveo can also take advantage of discards as a supplementary food resource to their traditional one;
- Scyliorhinus canicula and skates benefit most from discarding in the studied area, though it has to be borne in mind that such species have become very abundant in the area since the closure of the trawl fishery; and

- mature Scyliorhinus canicula $(>50 \mathrm{~cm})$ take the greatest advantage of the supplementary food provided by discarded Micromesistius poutassou.

\section{ACKNOWLEDGEMENTS}

We thank Drs Anna Bozzano (Instituto de Ciencias del Mar, Barcelona) and John Cotter (CEFAS, Lowestoft) for their useful comments and suggestions on the submitted manuscript. Sincere thanks are also due to the field assistants and crew aboard the R.V. Cornide Saavedra during the "Demersales 99" survey.

\section{REFERENCES}

Anon.. - 1997. Report of the International Bottom Trawl Survey Working Group. ICES Doc. C.M. 1997/H:6: 50 pp.

Bowering, W.R. and G.R. Lilly. - 1992. Greenland halibut (Reinhardtius hippoglossoides) off southern Labrador and northeastern Newfoundland (Northwest Atlantic) feed primarily on capelin (Mallotus villosus). Neth. J. Sea Res., 29(1-2): 211-222.

Camphuysen, C.J., B. Calvo, J. Dunrik, K. Ensor, A. Follestad, R. W. Furness, S. Garthe, G. Leaper, H. Kov, M. L. Tasker and C.J.N. Winter. - 1995. Consumption of discards by seabirds in the North Sea. NSRPDU, Den Burg, Texel. NIOZ-Rapport 1995-5: 202 pp.

Charnov, E.L. - 1976. Optimal foraging: the marginal value theorem. Theor. Pop. Biol., 9: 129-136.

Collins, M.A., C. Yau, C.P. Nolan, P.M. Bagley and I.G. Priede. 1999. Behavioural observations on the scavenging fauna of the Patagonian slope. J. mar. biol. Ass. U.K., 79: 963-970.

Demestre, M., P. Sánchez and M.J. Kaiser. - 2000. The behavioural response of benthic scavengers to otter-trawling disturbance in the Mediterranean. In: Kaiser, M. J. and S. J. De Groot (Eds), The effects of fishing on non-target species and habitats, pp. 121-129. Blackwell Science Ltd, Oxford.

Evans, P.L., M.J. Kaiser and R.N. Hughes. - 1996. Behaviour and energetics of whelks, Buccinum undatum (L.), feeding on animals killed by beam trawling. J. expl mar. Biol. Ecol., 197(1): 51-62.

Furness, R.W., A.W. Hudson and K. Ensor. - 1988. Interactions between scavenging seabirds and commercial fisheries around the British Isles. In: Burger, J. (Ed.), Seabirds and other marine vertebrates: competition, predation and other interactions, $\mathrm{pp}$. 240-268. Columbia University Press. New York.

Garthe, S., K. Camphuysen and R. Furness. - 1996. Amounts of discards by commercial fisheries and their significance as food for seabirds in the North Sea. Mar. Ecol. Prog. Ser: 136: 1-11.

Hall, S.J., M.R. Robertson, D.J. Basford and S.D. Heaney. - 1993. The possible effects of fishing disturbance in the northern North Sea: an analysis of spatial patterns in community structure around a wreck. Neth. J. Sea Res., 31: 201-208.

Hill, B.J. and T.J. Wassenberg. - 1990. Fate of discards from prawn trawlers in Torres Strait. Aust. J. mar. Freshwat. Res., 41(1): 53-64.

Hudson, A.V. and R.W. Furness. - 1988. Utilization of discarded fish by scavenging seabirds behind whitefish trawlers in Shetland. J. Zool., 215: 151-166.

Hyslop, E.J. - 1980. Stomach contents analysis: a review of methods and their application. J. Fish Biol., 17: 411-429. 
Kaiser, M.J. and K. Ramsay. - 1997. Opportunistic feeding by dabs within areas of trawl disturbance: possible implications for increased survival. Mar. Ecol. Prog. Ser., 152(1-3): 307-310.

Kaiser, M.J., K. Ramsay and R.N. Hughes. - 1998. Can fisheries influence interspecific competition in sympatric populations of hermit crabs? J. nat. Hist., 32(4): 521-531.

Kaiser, M.J. and B.E. Spencer. - 1994. Fish scavenging behaviour in recently trawled areas. Mar. Ecol. Prog. Ser., 112: 41-49.

Kaiser, M.J. and B.E. Spencer. - 1995. Survival of bycatch from a beam-trawl. Mar. Ecol. Prog. Ser., 126: 31-38.

Kaiser, M.J. and B.E. Spencer. - 1996. Behavioural responses of scavengers to beam trawl disturbance. In: Greenstreet, S.P.R. and M.L. Tasker (Eds.), Aquatic predators and their prey, pp. 117-123. Blackwell Science, Oxford.

Kislalioglu, M. and R.N. Gibson. - 1976. Prey 'handling time' and its importance in food selection by the 15-spined stickleback, Spinachia spinachia L. J. expl mar. Biol. Ecol., 25: 115-158.

Kock, K.H. - 1992. Antarctic fish and fisheries. University Press, Cambridge, 359 pp.

Laptikhovsky, V. and A. Fetison. - 1999. Scavenging by fish of discards from the Patagonian squid fishery. Fish. Res., 41(1): 93-97.

Lindeboom, H.J. and S.J. De Groot (Eds). - 1998. The effects of different types of fisheries on the North Sea and Irish benthic ecosystems. NSRPDU. NIOZ-Rapport 1998-1. RIVO-DLO Report C003/98, 404 pp., Texel (Netherlands).

Olaso, I. - 1990. Distribución y abundancía del megabentos invertebrado en fondos de la plataforma cantábrica. Publ. espec. Inst. Esp. Oceanogr., 15: 128 pp.

Olaso, I. and E. Rodríguez-Marín. - 1995a. Alimentación de veinte especies de peces demersales pertenecientes a la división VIIIc del ICES. Otoño 1991. Inf. téc. Inst. Esp. Oceanogr., 157: 56 pp.

Olaso, I. and E. Rodríguez-Marín. - 1995b. Decapod crustaceans in the diets of demersal fish in the Cantabrian Sea. ICES mar. Sci. Symp., 199: 209-221.

Olaso, I. and F. Velasco. - in Prep. Ecotrophic importance of mesopelagic fish in the Cantabrian Sea demersal fish community.

Olaso, I., F. Velasco and N. Pérez. - 1998. Importance of blue whiting (Micromesistius poutassou) discarded in the diet of lesserspotted dogfish (Scyliorhinus canicula) in the Cantabrian Sea. ICES J. mar. Sci., 55: 331-341.

Oro, D. and X. Ruiz. - 1997. Exploitation of trawler discards by breeding seabirds in the north-western Mediterranean: differences between the Ebro Delta and the Balearic Islands areas. ICES J. mar. Sci., 54(4): 695-707.

Pereda, P. and B. Villamor. - 1991. Relaciones biométricas en peces de la plataforma cantábrica. Inf. téc. Inst. Esp. Oceanogr., 92: 39 pp.

Pérez, N., P. Pereda, A. Uriarte, V. Trujillo, I. Olaso and S. Lens. -
1996. Descartes de la flota española en el área del ICES. Datos Resúm. Inst. Esp. Oceanogr., 2: 142 pp.

Ramsay, K. and M. J. Kaiser. - 1998. Demersal fishing disturbance increases predation risk for whelks (Buccinum undatum L.). $J$. Sea Res., 39(3-4): 299-304.

Ramsay, K., M.J. Kaiser and R.N. Hughes. - 1996. Changes in hermit crab feeding patterns in response to trawling disturbance. Mar. Ecol. Prog. Ser., 144(1-3): 63-72.

Ramsay, K., M.J. Kaiser and R.N. Hughes. - 1998. Responses of benthic scavengers to fishing disturbance by towed gears in different habitats. J. expl mar. Biol. Ecol., 224(1): 73-89.

Robb, A.P. - 1992. Changes in the gall bladder of whiting (Merlangius merlangus) in relation to recent feeding history. ICES J. mar. Sci., 49: 431-436.

Rodríguez-Cabello, C., F. Velasco and I. Olaso. - 1998. Reproductive biology of lesser-spotted dogfish Scyliorhinus canicula (L., 1758) in the Cantabrian Sea. Scientia Mar., 62(3): 187-191.

Rodríguez-Marín, E. - 1993. Biometry of decapod crustaceans in the Cantabrian Sea. Crustaceana, 65(2): 192-203.

Sánchez, F. - 1993. Las comunidades de peces de la plataforma del Cantábrico. Publ. espec. Inst. Esp. Oceanogr., 13: 137 pp.

Sánchez, F., N. Pérez and J. Landa. - 1998. Distribution and abundance of megrim (Lepidorhombus boscii and Lepidorhombus whiffiagonis) on the northern Spanish shelf. ICES J. mar. Sci., 55: 494-514.

Scharf, F.S., F. Juanes and R.A. Rountree. - 2000. Predator sizeprey size relationships of marine fish predators: interspecific variation and effects of ontogeny and body size on trophicniche breadth. Mar. Ecol. Prog. Ser., 208: 229-248.

Shannon, C.E. and W. Weaver. - 1949. The mathematical theory of communication. University of Illinois Press, Urbans.

Van Beek, F.A. - 1990. Discard sampling programme for the North Sea. Dutch participation. Internal RIVO report, Demvis, 90303: 24 pp.

Velasco, F. and I. Olaso. - 1998. European hake Merluccius merluccius (L., 1758) feeding in the Cantabrian Sea: seasonal, bathymetric and length variations. Fish. Res., 38: 33-44.

Velasco, F., I. Olaso and F. de la Gándara. - 1996. Alimentación de veintidós especies de peces demersales de la división VIIIc del ICES. Otoños de 1992 y 1993. Inf. téc. Inst. Esp. Oceanogr., 164: $62 \mathrm{pp}$

Wassenberg, T. and B.J. Hill. - 1987. Feeding by the sand crab Portunus pelagicus on material discarded from prawn trawlers in Moreton Bay, Australia. Mar. Biol., 95: 387-393.

Wassenberg, T. and B.J. Hill. - 1990. Partitioning of material discarded by prawn trawlers in Moreton Bay. Aust. J. mar. Freshwat. Res., 41: 27-36.

Scient. ed.: A.I.L. Payne 